\title{
Modern Data on the Spatial Distribution of the Baikal Amphipods in the Yenisei River and Their Visualization in the Geoinformational Web System
}

\author{
A. V. Andrianova ${ }^{a, b, *}$, O. E. Yakubailik ${ }^{a, c}$, and Y. V. Shan'ko ${ }^{a}$ \\ ${ }^{a}$ Institute of Computational Modeling, Siberian Branch, Russian Academy of Sciences, Krasnoyarsk, 660036 Russia \\ ${ }^{b}$ Scientific Research Institute of Ecology of Fishery Reservoirs, Krasnoyarsk, 660097 Russia \\ 'Siberian Federal University, Krasnoyarsk, 660041 Russia \\ *e-mail: andrav@icm.krasn.ru \\ Received March 16, 2018
}

\begin{abstract}
The results of hydrobiological studies of expeditions conducted in 2015-2016 in several zones of the Yenisei River from its head to the mouth are presented. This work deals with the spatial dynamics of the amphipod community, in which the leading positions are occupied by invaders from Baikal. The invaders spread through the Angara River not only with the current but also against the current of the Yenisei. Eight species of amphipods were identified, and there were two representatives of native fauna (Pontoporeia affinis and Gammarus sp.) and six Baikal endemics among them. Throughout the river, Gmelinoides fasciatus dominated quantitatively among the gammarids; Philolimnogammarus viridis took second place. Only in the lower reaches and in the delta of the Yenisei were the leading positions surrendered to Pontoporeia affinis-a representative of the estuary-relic complex of organisms. Baikal endemics populated actively the Upper Yenisei section below the Sayano-Shushensky hydroelectric power station (HPS), especially in the areas of massive macrophyte distribution. The main vector of Baikal endemics spreading in the Yenisei is self-colonization through the Angara River, noticed by researchers in the 19th century. For G. fasciatus, its intentional introduction into the Krasnoyarsk Reservoir in the late 1960s with the aim of increasing the food supply was an additional stimulus for the growth of the population below and above the Krasnoyarsk HPS. Naturalization of $P h$. viridis in the Upper Yenisei section was probably aided by an accidental introduction. There is a divergence of ecological niches in G. fasciatus and Ph. viridis in the Yenisei: the dominant prefers silty sand-andshingle biotopes with a calm rate of speed; the subdominant tends to prefer stony-pebble bottom washed by a rapid current. Over the last 15 years, the density and proportion of crustaceans in the zoobenthos have increased in the Angara-Podkamennaya Tunguska section. The results of hydrobiological studies have been designed in the form a geospatial database in a geoportal, which makes it possible to visualize information as interactive thematic maps and which provides the direct access to data via web mapping services from the modern GIS software.
\end{abstract}

Keywords: Yenisei River, invade rs, Baikal en demics, amphipods, Gmelinoides fasciatus, Philolimnogammarus viridis, biotopes, spatial distribution, geographic informational system, geoportal

DOI: $10.1134 / \mathrm{S} 2075111718040021$

\section{INTRODUCTION}

It is known that crustaceans are one of the most active hydrobionts, spreading beyond their natural ranges. Amphipods are one of the dominant groups of higher crustaceans in terms of species and quantity, which have mastered a variety of marine, continental, groundwater, and even partly terrestrial habitats (suborder Talitroidea) (Takhteev et al., 2015). According to taxonomic diversity, the fauna of amphipods in Lake Baikal has no analogs among the continental reservoirs of the world. In order to enrich the food supply of fish, the Baikal amphipods were successfully introduced into many reservoirs and lakes of the Soviet Union, and they also entered them as a result of acci- dental introductions (Matafonov et al., 2006; Barbashova et al., 2013). The invasions of these organisms lead to significant changes in recipient reservoirs, in particular, to the reduction of species diversity and stability of aquatic ecosystems (Berezina, 2007).

The Angara historically serves as a donor of the endemic Baikal fauna penetrating into the middle reaches of the Yenisei River. Thus, the Baikal type of sculpins, stone sculpin (Paracottus knerii (Dybowski, 1876)), is found massively in the Yenisei in the section from Krasnoyarsk to the mouth of the Angara (Zuev et al., 2016). Back in the 19th century, B. Dybowski first established that amphipods of Baikal origin extend from Lake Baikal to the middle course of the 
Angara (Kamaltynov, 2009). E.F. Guryanova found the first forms of Baikal amphipods in the Yenisei (Guryanova, 1929).

It is known that the emergence of large hydraulic structures causes a prolonged and sometimes irreversible destabilization of aquatic ecosystems. With the commissioning of the Krasnoyarsk HPS (Kras-HPS), the Yenisei River has undergone a radical change in the hydrological, hydrochemical, and hydrobiological regimes. The Yenisei in the lower pool of the KrasHPS does not freeze in winter over the length of 100 $300 \mathrm{~km}$ from the dam; the influence of hydropower stations on the ice regime of the river is traced to the mouth of the Podkamennaya Tunguska River (Kosmakov et al., 2011). There was a change in the dominant forms of phytoplankton, an enrichment of its species composition, and an increase in the total abundance of algae due to runoff from the upper pool (Ponomareva and Ivanova, 2016). The quantity of phytobenthos and phytoperiphyton increased sharply, which even became an obstacle in the work of water intakes. The change in the hydrological regime had a negative impact on populations of sturgeon, salmon, whitefish, and other valuable fish species, significantly disturbing their habitats (Zadelenov, 2000).

As a result of hydroelectric construction, zoobenthos of the Yenisei has also undergone large-scale restructuring, especially in the lower pool of the KrasHPS. Stone flies and midges have practically disappeared from the benthic fauna, and the density and number of species of caddis flies and dayflies have significantly decreased. The quantitative characteristics of the zoobenthos in the area from the Kras-HPS dam to the mouth of the Angara River have increased significantly: the number has increased more than twofold, and the biomass has increased fivefold. The growth of the indicators was primarily due to the increase in the number of amphipods of Baikal origin, while their proportion in the total zoobenthos biomass increased tenfold (Komlev, 1981; Gladyshev and Moskvichyova (Andrianova), 2002; Andrianova, 2013). In the early 2000s, five species of Baikal endemics and only one representative of the native fauna (Gammarus sp.) were recorded in the amphipod community; the leading positions belonged to Philolimnogammarus viridis Dybowsky, 1874 and Gmelinoides fasciatus Stebbing, 1899.

Despite the extensive volume of publications on the expansion of amphipods beyond the natural ranges, there is a lack of up-to-date information about their fate in one of the largest rivers in the world, the Yenisei. Large-scale complex works on the study of the Yenisei were carried out even before the beginning of hydroelectric construction (Greze, 1957); subsequent studies are fragmentary and do not fully reflect the representation of amphipod communities in the Yenisei (Komlev, 1981; Zadelyonov, 2000; Gladyshev and Moskvichyova (Andrianova), 2002; Gadinov, 2007;
Andrianova, 2013; Gladyshev et al., 2016). At the same time, the study of the spatial distribution of biota is one of the main directions of hydrobiology.

Special attention should be paid to the methods of visualization of the hydrobiological data being studied and to ensuring their wide availability. Until recently, there were no effective ways to solve these problems in the world, but now this possibility has been created by technologies of geoinformation systems (GIS) and the Internet. After entering the hydrobiological information in the GIS, it can be shown on maps, that is, published on the Internet using interactive cartographic web services-geoportal technologies, or web GIS. Users are given the opportunity to control the display of the data under study - the choice of the scale and the desired fragment of the map (with the automatically adapted level of detail of the displayed geodata), the use of various base maps (maps or satellite imagery of Google, Yandex, etc.), displaying the coordinates of objects on the map (degrees of latitude/longitude or meters of a user-selected cartographic projection), visualization of a table information on the objects under study. The current level of implementation of systems of this type is intuitively understandable and does not require special knowledge in the field of information technology or preliminary training of users. This approach ensures the availability of data for general use and makes information about their availability widely known.

The use of new methods of data processing, such as geoinformation and cartographic modeling, provides the opportunity to obtain additional information on spatial features of the distribution of hydrobionts and helps in the search for relationships with various environmental factors.

The purpose of this work is to analyze the features of the spatial distribution of the Baikal endemic amphipods throughout the Yenisei River and visualize the acquired up-to-date data with the help of geoinformation systems, geoportals, and cartographic web services.

\section{MATERIALS AND METHODS}

The Yenisei flows in the center of Russia in the meridional direction to the north, and its length is $3487 \mathrm{~km}$. On its way it crosses the mountain-taiga, steppe, forest, and tundra natural zones. According to the physical and geographical conditions, the water regime, and the nature of the structure of the valley and the Yenisei River bed, it is divided into the mountain Upper (the source of the Yenisei-the mouth of the Angara River), the piedmont Middle (the Angara River-the mouth of the Nizhnaya Tunguska River), and the plain Lower (the mouth of the Nizhnaya Tunguska River-the mouth of the Yenisei River) sections (Greze, 1957). The Yenisei flows through three regions of the Russian Federation: in the upper 
reaches are the Republics of Tyva and Khakassia; the main part of the river is located in Krasnoyarsk krai.

The Yenisei River belongs to oligotrophic watercourses. The reason for this lies in the mountain nature inherent in the Yenisei up to the mouth of the Angara. The Yenisei originates at an elevation of $660 \mathrm{~m}$ above sea level, the middle course is at about $100 \mathrm{~m}$, and the lower course is $40 \mathrm{~m}$ above sea level. The tributaries, which flow mainly from the right bank, are of mountainous and piedmont nature and carry slightly mineralized waters collected in the areas of distribution of solid rocks and podzolic soils, poor in mineral salts. In addition, an important morphological feature of the riverbed, which also has a negative impact on the overall productivity of the river, is the very weak development of the floodplain system-from the mountain tops to the bay, the Yenisei mainly flows in a narrow valley with narrow banks (Greze, 1957; Levadnaya, 1986).

The upper current of the Yenisei occupies up to $39 \%$ of the river's extent and is distinguished by high flow velocities and the dominance of stony soils. After the merger with the Angara, the whole character of the river changes. Its width increases sharply, the flow becomes calmer. The Yenisei enters the middle course, acquiring the features of a large plain river. Pebbly and sandy washable sediments are also characteristic of the middle part of the river, but the proportion of sand and silting of the bed increases. Overgrowing of the coastal area by higher aquatic vegetation, as before, is not high; macrophyte overgrowing occurs locally.

After joining the waters of the Lower Tunguska, the Yenisei enters the area of the lower reaches, continuing until the delta near Ust-Port. In the region of Ust-Port, an increasing number of ducts form an extensive delta from the Yenisei channel. The delta archipelago is known as the Brekhov Islands. By the lower course of the Yenisei, the stony pebble soils are completely replaced by sandy-muddy soils. The accumulation of silty deposits on a large scale begins only in the delta (Greze, 1957; Levadnaya, 1986).

The regulation of the Upper Yenisei by the dams of the Sayano-Shushenskaya, Maina, and Krasnoyarsk hydropower stations, the creation of the Khantay and Kureisk reservoirs on the tributaries of the Lower Yenisei, and the flow of sewage led to an increase in the trophicity of the watercourse (Sorokovikova and Bashenkhayeva, 2000). At present, the natural hydrological regime of the Yenisei has been preserved on the site from the source to the reserve zone of the SayanoShushenskoye Reservoir and also below the mouth of the Angara.

During the growing seasons of 2015 (July, August) and 2016 (July-September), macrozoobenthos was collected in the Yenisei River from the source to the delta inclusive. In the Upper Yenisei, hydrobiological material was collected at 15 stations: 2 of them are located within the Republic of Tyva, 3 are below the Sayano-Shushenskoye Reservoir from Sayanogorsk to Minusinsk, and 10 are from the Kras-HPS dam to the mouth of the Angara River. In the Middle Yenisei, a site from the mouth of the Angara River to the village of Surgutikha was investigated-21 stations; in the Lower Yenisei, zoobenthos was collected at 12 stations-from Dudinka to the delta, including the Brekhov Islands. For each station, geographic coordinates were determined, which became the basis for the creation of the geoinformation system. All the detailed information on the geographical location of the stations (coordinates in degrees of latitude and longitude, distance from the mouth in kilometers) is entered into the geo-information system (Geoportal of the ICM..., 2018a), which has a set of tools for measuring the distances between derived points on the map.

Samples were taken from both banks, mainly in ripals at a depth of $1 \mathrm{~m}$; only in the delta of the Yenisei was it possible to collect the soil from depths of up to $14 \mathrm{~m}$. Depending on the type of soil and hydrological conditions, a loaded Petersen bottom grab (gripping area of $0.025 \mathrm{~m}^{2}$ ) and also quantitative frames, bentometers, and scrapers (gripping area of $0.06-0.13 \mathrm{~m}^{2}$ ) were used.

The speed of the current in the section from the Kras-HPS dam to the mouth of the Angara River was measured using surface floats. All the information obtained about the speed characteristics of the Yenisei was compared with the data of the stationary posts of the Central Siberian UGMS and various published data. To estimate the influence of the flow velocity on the distribution of amphipods, two samples were formed: (1) samples collected at an elevated current (above the average flow velocity of $1 \mathrm{~m} / \mathrm{s}$ )-mainly in the main bed; (2) samples collected at a slow current (below the average flow velocity) -in creeks and ducts.

At each station, 2-5 soil samples were taken; for this study, 178 quantitative samples of benthic fauna were collected and analyzed in the Yenisei. Ground samples were disassembled in field conditions; invertebrate animals were fixed in $70 \%$ ethyl alcohol; in the laboratory, the zoobenthos samples were processed; the material was analyzed by conventional hydrobiological methods (Rukovodstvo..., 1992). The species affiliation of amphipods was established according to Basikalova (1945) and the manual under the editorship of S.Ya. Tsalolikhin (Opredelitel'..., 1995).

To analyze the temporal changes, we used our own data collected during 2000-2003 in a similar vegetation period (Andrianova, 2013).

Statistical analysis of the data was carried out using the Excel and R programs (R Core Team, 2014). In connection with the deviation of data from the normal distribution, nonparametric statistical methods were applied in all the analyzed samples. When comparing samples (for example, the number and biomass of amphipods on different types of soil), the Kolmog- 
orov-Smirnov test and the Mann-Whitney U test were used. As an additional statistical treatment, an analysis of variance of data was carried out to evaluate the influence of various types of soil on the density of amphipods. In calculating the coefficients of determination, we used the logarithms of the initial data. To avoid the appearance of a logarithm of zero, before taking logarithms, one was added to each value. The null hypothesis about the identity of the distribution laws of samples of random variables was rejected for $p<0.05$. The averages are presented with a standard error.

To visualize the results of hydrobiological research, an approach based on the technologies of geoinformation web systems was used. Formation of the base of geo-positioned data of hydrobiological research was carried out on the basis of all the initial informationvarious characteristics of research objects were introduced, and their location was specified by geographical coordinates. The developed applied geoinformation web system allowed connecting the initial geographic coordinates of the objects with the coordinates (kilometer marks) of the river fairway, thus ensuring the possibility of analyzing changes in hydrobiological characteristics along the river. In turn, the interactive cartographic web interface provides the user with intuitive access to any parameters of the monitoring stations-their geographical and linear coordinates and the recorded data.

\section{RESULTS AND DISCUSSION}

\section{Spatial Dynamics of Amphipods}

In the Yenisei, we discovered eight species of amphipods, among them two representatives of native fauna (Pontoporeia affinis Lindstrom and Gammarus sp.) and six Baikal endemics. Throughout the river, there was only Gmelinoides fasciatus Stebb. In the Upper Yenisei in the territory of the Republic of Tyva, it was the only and rare representative of the higher crustaceans; Philolimnogammarus viridis Dybowsky joined it below the Sayano-Shushenskoye Reservoir. Below the Kras-HPS dam, the species composition of the amphipods in our collections expanded owing to Gammarus sp., Ph. cyaneus Dybowsky, Pallasea cancelloides Gerstfeldt, and Eulimnogammarus verrucosus Gerstfeldt. In the Middle Yenisei after the confluence of the Angara, this complex of amphipods persisted, but Gammarus sp. was replaced by Micruropus sp. In the Lower Yenisei, P. affinis acquired the greatest weight, while $P h$. cyaneus and E. verrucosus, on the contrary, were absent in the samples.

The number of amphipods in the various zones of the Yenisei varied considerably. In the uppermost area investigated (Republic of Tyva), amphipods are extremely poor in conditions of high flow velocity and coarse rocky-pebble soil: only G. fasciatus was sporadically observed. The maximum density of the amphi- pods was below the Sayano-Shushenskoye Reservoir in the region of the cities of Sayanogorsk and Minusinsk (3800 ind. $/ \mathrm{m}^{2}$ and $10.4 \mathrm{~g} / \mathrm{m}^{2}$ ), while their proportion in the zoobenthos averaged $70 \%$ of the population and $53 \%$ of the biomass (Table 1). Further downstream, the number of amphipods decreased and in the Lower Yenisei fell to an average of 300 specimens $/ \mathrm{m}^{2}$ with a biomass of $0.6 \mathrm{~g} / \mathrm{m}^{2}$ (13\% of abundance and $7 \%$ of biomass of benthic fauna).

The quantitative advantage in the investigated areas of the Yenisei belonged to G. fasciatus and, to a lesser extent, Ph. viridis; in the delta, they were replaced by P. affinis (Table 1). The spatial dynamics of the quantitative indices of the dominant species of amphipods in all the investigated sections of the Yenisei was characterized by extreme heterogeneity.

G. fasciatus in the Upper Yenisei was present in all collected samples, reaching a maximum density in the region of Sayanogorsk (3018 km from the mouth of the Yenisei) and Minusinsk (2901 km): up to $17600 \mathrm{ind} . / \mathrm{m}^{2}$ and $25.6 \mathrm{~g} / \mathrm{m}^{2}$. The average indices at these stations were more than 4000 ind. $/ \mathrm{m}^{2}$ and $7-8 \mathrm{~g} / \mathrm{m}^{2}$ (Fig. 1). It should be noted that, in this section in the Yenisei, the degree of overgrowing of the channel by submerged and semi-submerged macrophytes is high, which serve as a favorable biotope for the mass development of $G$. fasciatus. Another quantitative burst of G. fasciatus in the Upper Yenisei is noted below Krasnoyarsk (Kubekovo, $2439 \mathrm{~km}$ ) near the left bank on muddy soil; the number here reached 6300 ind. $/ \mathrm{m}^{2}$ and the biomass reached $9.3 \mathrm{~g} / \mathrm{m}^{2}$. The low density of gmelinoides in the Upper Yenisei was recorded after the Kras-HPS dam $(2500,2482 \mathrm{~km})$ and in the area of the mouth of the right-bank inflow of the Kan River $(2356 \mathrm{~km})-$ less than 100 ind. $/ \mathrm{m}^{2}$ with biomass of $0.2-0.8 \mathrm{~g} / \mathrm{m}^{2}$.

In the Middle Yenisei (after the confluence of the Angara), the occurrence of G. fasciatus was $80 \%$; high abundance was noted at several stations within 2095$1863 \mathrm{~km}$ from the mouth (Fig. 1). The maximum concentrations were detected in Bazhenovskaya Kurya Bay $(2008 \mathrm{~km})$ and the Elovaya Channel $(1863 \mathrm{~km})-$ up to $4200 \mathrm{ind} . / \mathrm{m}^{2}$ and $17.0 \mathrm{~g} / \mathrm{m}^{2}$. After the confluence of the left-bank tributary of the Kas River $(1819 \mathrm{~km}$ from the mouth), G. fasciatus was found only in half of the collected samples; its density in the Yenisei dropped sharply and did not exceed 800 ind. $/ \mathrm{m}^{2}$ and $3.0 \mathrm{~g} / \mathrm{m}^{2}$. Only at the end of the investigated section of the Middle Yenisei in the vicinity of Surgutsky $(1235 \mathrm{~km})$ was there an accumulation of amphipods near the right bank numbering 1300 ind. $/ \mathrm{m}^{2}$ with a biomass of $3.8 \mathrm{~g} / \mathrm{m}^{2}$. A sharp decrease in the density of the amphipods on the lower reach of the Middle Yenisei is probably due to the hydrological features of this section, since after the confluence of the Podkamennaya Tunguska River the channel slope decreases by a factor of two, which leads to a decrease in the flow rate and to the accumulation 
Table 1. Number (in numerator, ind. $/ \mathrm{m}^{2}$ ) and biomass (in denominator, $\mathrm{g} / \mathrm{m}^{2}$ ) of zoobenthos and amphipods in the Yenisei River

\begin{tabular}{|c|c|c|c|c|}
\hline Section of the Yenisei & Zoobenthos & Amphipods & G. fasciatus & Ph. viridis \\
\hline \multicolumn{5}{|c|}{ Upper Yenisei: } \\
\hline Republic of Tyva & $\frac{612 \pm 93}{4.20 \pm 1.68}$ & Sporadically & Sporadically & Abcent \\
\hline Sayanogorsk-Minusinsk & $\frac{5501 \pm 2186}{19.5 \pm 4.09}$ & $\frac{3809 \pm 1682(69)}{10.4 \pm 3.90(53)}$ & $\frac{3398 \pm 1450}{6.47 \pm 2.33}$ & $\frac{411 \pm 272}{3.96 \pm 2.16}$ \\
\hline Kras-HPS-mouth of the Angara River & $\frac{2769 \pm 509}{10.5 \pm 2.51}$ & $\frac{962 \pm 311(35)}{4.97 \pm 1.72(47)}$ & $\frac{705 \pm 311}{1.29 \pm 0.45}$ & $\frac{177 \pm 76}{1.90 \pm 0.95}$ \\
\hline \multicolumn{5}{|c|}{ Middle Yenisei: } \\
\hline Mouth of the Angara River-Surgutikha & $\frac{1423 \pm 150}{6.44 \pm 0.73}$ & $\frac{643 \pm 121(45)}{3.22 \pm 0.53(50)}$ & $\frac{486 \pm 104}{1.72 \pm 0.38}$ & $\frac{60 \pm 13}{0.86 \pm 0.22}$ \\
\hline \multicolumn{5}{|c|}{ Lower Yenisei: } \\
\hline Dudinka-Delta & $\frac{2234 \pm 419}{8.55 \pm 1.66}$ & $\frac{288 \pm 81(13)}{0.60 \pm 0.13(7)}$ & $\frac{67 \pm 26}{0.22 \pm 0.09}$ & $\frac{201 \pm 79^{*}}{0.32 \pm 0.1^{*}}$ \\
\hline
\end{tabular}

In parentheses-the proportion of amphipods (\%) in zoobenthos; asterisk-number and biomass of P. affinis.

of silt sediments (Greze, 1957). Minimum indices of G. fasciatus $\left(10 \mathrm{ind} . / \mathrm{m}^{2}\right.$ with biomass of $0.07 \mathrm{~g} / \mathrm{m}^{2}$ ) are noted in the region of Vorogovskoye Mnogoostrovye $(1636 \mathrm{~km})$, which is important for the development and feeding of young sturgeon, as their spawning grounds are located here. The site is distinguished by a large number of islands, ducts, and creeks and by a large area of shallow water; here, muddy soils are especially widespread.

In the lower reaches, strong winds, especially in autumn, cause frequent storms and sudden fluctuations in the water level. The strong surf action of the waves adversely affects the inhabitants of the coastal zone, usually composed here of easily eroded soils. The density of $G$. fasciatus in the lower reaches of the Yenisei fell sharply compared with the upper sections (Table 1); its occurrence in the samples was only $26 \%$. The maximum quantitative indices (abundance of 1100 ind. $/ \mathrm{m}^{2}$ with biomass of $3.9 \mathrm{~g} / \mathrm{m}^{2}$ ) were identified locally in the Malyi Yenisei channel (Brekhov Islands), but the average density of $G$. fasciatus (Fig. 2) did not exceed 120 ind. $/ \mathrm{m}^{2}$ and $0.5 \mathrm{~g} / \mathrm{m}^{2}$ (the region of Dudinka, $424 \mathrm{~km}$ from the mouth).

Ph. viridis. According to our data, the abundance of this species in the Yenisei is much lower than that of G. fasciatus, but it is a stable subdominant among amphipods, with the exception of the Lower Yenisei, where it is replaced by $P$. affinis.

In the Upper Yenisei, in Tyva, Ph. viridis was absent in the samples, but downstream in the SayanogorskMinusinsk section, its occurrence was already over $70 \%$. Here it reached the maximum quantitative indices (Table 1, Fig. 1), especially in the macrophyte thickets near Sayanogorsk (3018 $\mathrm{km}$ from the mouth) - up to 3900 ind. $/ \mathrm{m}^{2}$ with biomass of $29 \mathrm{~g} / \mathrm{m}^{2}$. Two more density peak of $P h$. viridis were also confined to the Upper Yenisei, but to the lower reach-from the Kras-HPS dam to the mouth of the Angara River. The left-bank station near the dam (2500 km from the mouth) was characterized by a relatively high flow rate and a gravel artificial substratum in the coastal region, where the number of $P h$. viridis reached 1400 ind. $/ \mathrm{m}^{2}$ with biomass of $9 \mathrm{~g} / \mathrm{m}^{2}$. The next peak was found already below Krasnoyarsk in the region of Rossiyka (2288 km) (Fig. 1): the largest population was $1100 \mathrm{ind} . / \mathrm{m}^{2}$ with biomass of $19.6 \mathrm{~g} / \mathrm{m}^{2}$ at the left bank, also at a high flow rate, as well as at the Kras-HPS dam. The least populated by $P h$. viridis is the section of the Upper Yenisei from village of Ovsyanka (above Krasnoyarsk, $2482 \mathrm{~km}$ from the mouth) to the confluence of the right-bank tributary of the Kan River (below Krasnoyarsk, 2356 km from the mouth). Here, the crustacean was present only in $40 \%$ of samples, its abundance did not exceed 20 ind. $/ \mathrm{m}^{2}$, and biomass was $0.2 \mathrm{~g} / \mathrm{m}^{2}$.

In the Middle Yenisei below the mouth of the Angara, the occurrence of Ph. viridis was 50\%, while the dynamics of the density was characterized by several smooth increases, which, however, were significantly lower than in the Upper Yenisei. The first increase is confined to the region of Lesosibirsk (2095 km from the mouth), the second is confined to the mouth of the Kas River (1819 km), and the third is marked in the section from the village of Bor (below the mouth of the Podkamennaya Tunguska River) to the village of Bakhta (1553-1434 km) (Fig. 1). The maximum indicators of the number and biomass of the crustacean 

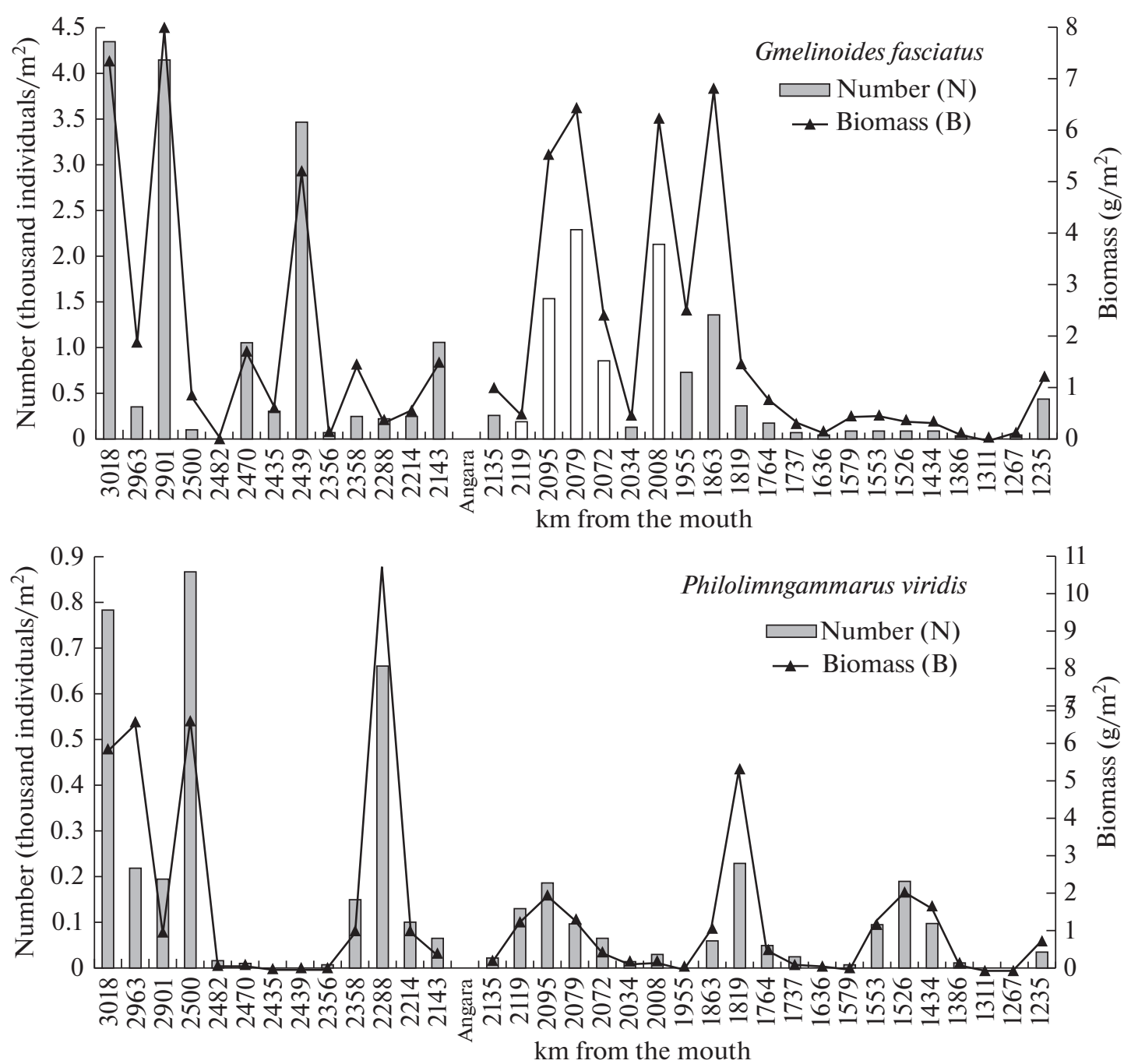

Fig. 1. Spatial dynamics of number and biomass of G. fasciatus and Ph. viridis in the Upper (above the confluence of the Angara River) and the Middle Yenisei (below the confluence of the Angara River).

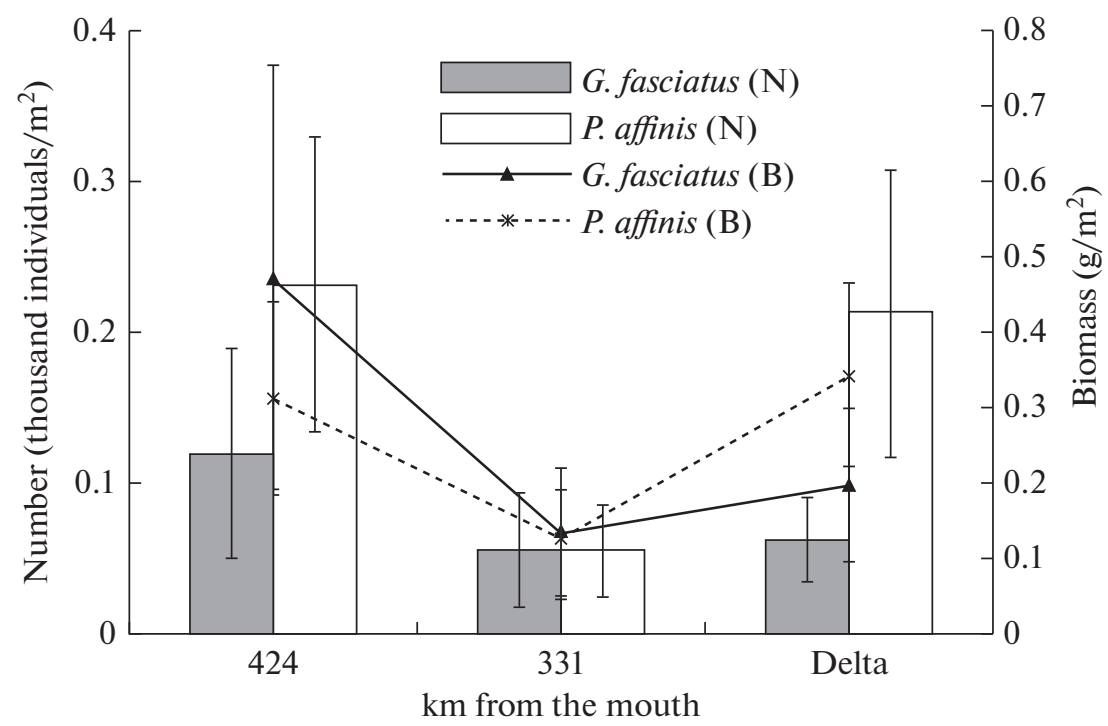

Fig. 2. Spatial dynamics of number and biomass of G. fasciatus and P. affinis in the Lower Yenisei. 
Table 2. Number (in numerator, ind./ $\mathrm{m}^{2}$ ) and biomass (in denominator, $\mathrm{g} / \mathrm{m}^{2}$ ) of the dominant species of amphipods in the Upper Yenisei on different types of soil (Sayanogorsk-Minusinsk) and at different flow rates (Kras-HPS sectionmouth of the Angara River)

\begin{tabular}{l|c|c|c|c|c}
\hline Amphipod species & $\begin{array}{c}\text { Stones, pebbles } \\
(n=10)\end{array}$ & $\begin{array}{c}\text { Silty sands } \\
(n=7)\end{array}$ & $\begin{array}{c}\text { Among } \\
\text { macrophytes }(n=7)\end{array}$ & $\begin{array}{c}V_{\text {flow }}<1.0 \mathrm{~m} / \mathrm{s} \\
(n=15)\end{array}$ & $\begin{array}{c}V_{\text {flow }}>1.0 \mathrm{~m} / \mathrm{s} \\
(n=10)\end{array}$ \\
\hline G. fasciatus & $\frac{559 \pm 123^{1}}{1.93 \pm 0.40^{9}}$ & $\frac{1212 \pm 292^{2}}{2.56 \pm 0.68^{10}}$ & $\frac{12936 \pm 2335^{3}}{22.3 \pm 1.87^{11}}$ & $\frac{1122 \pm 628}{1.82 \pm 0.92}$ & $\frac{163 \pm 34}{0.68 \pm 0.21}$ \\
\hline Ph. viridis & $\frac{116 \pm 59^{4}}{3.28 \pm 1.86}$ & $\frac{24 \pm 11^{5}}{0.42 \pm 0.25}$ & $\frac{1617 \pm 998^{6}}{10.3 \pm 6.37}$ & $\frac{56 \pm 24^{7}}{0.46 \pm 0.20^{12}}$ & $\frac{736 \pm 287^{8}}{8.48 \pm 4.04^{13}}$ \\
\hline
\end{tabular}

1-13_Differences are statistically significant between samples in terms of numbers: $1-3,2-3,1-2,4-6,5-6,7-8$; in terms of biomass: 9-11, 10-11, 9-10, 12-13.

(500 ind. $/ \mathrm{m}^{2}$ and $11.7 \mathrm{~g} / \mathrm{m}^{2}$ ) were found in the region of Kasovsky Island $(1819 \mathrm{~km})$ on pebble ground. In the Lower Yenisei, only one specimen of Ph. viridis was found in our collections.

$\boldsymbol{P}$. affinis in the lower reaches of the Yenisei is the most widespread representative of the estuary-relic complex of organisms, neolymic emigrants from the Arctic Ocean basin. Besides the Yenisei, the crustaceans inhabit estuaries and lower parts of the northern and Far Eastern rivers, brackish areas along the coast of Alaska and Canada, the Baltic and Caspian seas, and numerous lakes in the north of Eurasia and America. This is a widely euryhaline species that can tolerate sharp fluctuations in the salinity of water over a wide range (from 1 to 20\%o) (Filippov, 2006). The crustaceans are typical inhabitants of deep-sea habitats at a temperature of $4-5^{\circ} \mathrm{C}$ and are found in mass in places with a reduced content of dissolved oxygen in the bottom water layer (down to $4 \mathrm{mg} / \mathrm{L}$ ) (Berezina and Maksimov, 2016). These and other factors determine the wide distribution of this species and its significant role in benthic communities.

In our collections from the lower reaches of the Yenisei, P. affinis was found in half of the samples. The maximum concentration of crustaceans was recorded in the channels of the Okhotskaya Delta and Deryabinsky Yenisei among the Brekhov Islands-the number reached 3800 ind. $/ \mathrm{m}^{2}$ with biomass up to $5 \mathrm{~g} / \mathrm{m}^{2}$. The lowest density was recorded above the village of UstPort (331 km from the mouth) - on average, 56 individuals $/ \mathrm{m}^{2}$ with biomass of $0.12 \mathrm{~g} / \mathrm{m}^{2}$ (Fig. 2).

\section{Distribution of Amphipods on Different Types of Soil}

The factors influencing the distribution pattern of hydrobionts in the river system have not been sufficiently studied and, apparently, can differ substantially in different river basins. However, it is generally accepted that the distribution of macroinvertebrates in a watercourse is influenced by such abiotic factors as flow rate, water temperature, watercourse depth, and particle size of the substrate (Malmqvist, 2002). We attempted to elucidate the features of the quantitative distribution of the dominant amphipods (G. fasciatus, $P h$. viridis, and $P$. affinis), depending on the type of substrate.

In the Upper Yenisei, a sufficient amount of material for statistical processing was collected only on the upper layer (the section of Sayanogorsk-Minusinsk) (Table 2). The soils here are predominantly rocky and pebbly, and biotopes of silted sand are distributed to a lesser extent. In addition, macrophyte communities actively develop in the riverbed, in which the bulk of amphipods were concentrated. The number and biomass of $G$. fasciatus in phytophilic communities statistically significantly increased in comparison with pebble and silt-sandy biotopes. For Ph. viridis, we noted the same pattern, but the reliability of differences for biomass is not statistically confirmed. In addition, it was revealed that the number of $G$. fasciatus on silted sand is significantly higher than on stony-pebble soil, which, on the contrary, was more preferable for Ph. viridis. However, the laws of distribution of samples for $P h$. viridis are identical.

The speed of the current is one of the essential factors determining the composition and distribution of aquatic organisms in the river. Its influence on hydrobionts is expressed either directly by the action of the water jet or indirectly (distribution of soils, amount of suspended sediment, changes in hydrochemistry and thermal conditions, etc.).

The volume of the material collected by us on the lower slope of the Upper Yenisei (from the Kras-HPS dam to the mouth of the Angara River) makes it possible to estimate the influence of the flow rate on the amphipod distribution (Table 2). In this area, mainly pebble soils with a certain degree of silting are common, depending on the flow rate, which varies from 0.5 to $2.0 \mathrm{~m} / \mathrm{s}$ in different sources. The flow rate above $1 \mathrm{~m} / \mathrm{s}$ can be taken as "high." It was revealed that G. fasciatus prefers biotopes in conditions of reduced flow rate, whereas Ph. viridis, on the contrary, concentrates in areas with high flow rate (Table 2). However, the null hypothesis about the identity of the sample distribution is rejected only for Ph. viridis. Dispersion analysis showed that, for $P h$. viridis, the flow rate 
Table 3. Number (in numerator, ind. $/ \mathrm{m}^{2}$ ) and biomass (in denominator, $\mathrm{g} / \mathrm{m}^{2}$ ) of the dominant species of amphipods on different types of soil in the Middle Yenisei (mouth of the Angara River-Surgutikha village)

\begin{tabular}{l|c|c|c|c|c}
\hline Amphipod species & $\begin{array}{c}\text { Pebble with sand } \\
(n=34)\end{array}$ & $\begin{array}{c}\text { Silty pebble } \\
\text { with sand }(n=18)\end{array}$ & Sand $(n=18)$ & $\begin{array}{c}\text { Among macrophytes } \\
(n=22)\end{array}$ & $\begin{array}{c}\text { Without macrophytes } \\
(n=48)\end{array}$ \\
\hline G. fasciatus & $\frac{534 \pm 128^{1}}{1.81 \pm 0.43^{6}}$ & $\frac{1105 \pm 505^{2}}{4.25 \pm 2.05^{7}}$ & $\frac{94 \pm 58^{3}}{0.38 \pm 0.23^{8}}$ & $\frac{1023 \pm 393}{3.48 \pm 1.36}$ & $\frac{375 \pm 92}{1.35 \pm 0.35}$ \\
\hline Ph. viridis & $\frac{66 \pm 18^{4}}{0.94 \pm 0.30^{9}}$ & $\frac{151 \pm 39^{5}}{2.29 \pm 0.75^{10}}$ & Sporadically & $\frac{108 \pm 51}{1.58 \pm 0.98}$ & $\frac{50 \pm 11}{0.71 \pm 0.17}$ \\
\hline
\end{tabular}

1-5_Differences are statistically significant between samples in terms of numbers: $1-3,2-3,4-5$; in terms of biomass: 6-8, 7-8, 9-10.

Table 4. Number (in numerator, ind. $/ \mathrm{m}^{2}$ ) and biomass (in denominator, $\mathrm{g} / \mathrm{m}^{2}$ ) of the dominant species of amphipods on different types of soil in the Lower Yenisei (Dudinka-Brekhov Islands)

\begin{tabular}{l|c|c|c|c|c}
\hline Amphipod species & $\begin{array}{c}\text { Silty sand } \\
(n=35)\end{array}$ & Silt $(n=16)$ & Sand $(n=8)$ & $\begin{array}{c}\text { Among macrophytes } \\
(n=11)\end{array}$ & $\begin{array}{c}\text { Without macrophytes } \\
(n=48)\end{array}$ \\
\hline G. fasciatus & $\frac{76 \pm 39}{0.26 \pm 0.14}$ & Absent & Sporadically & $\frac{170 \pm 92}{0.52 \pm 0.34}$ & $\frac{60 \pm 27}{0.22 \pm 0.1}$ \\
\hline P. affinis & $\frac{139 \pm 31}{0.30 \pm 0.08}$ & $\frac{608 \pm 492}{0.70 \pm 0.55}$ & Sporadically & $\frac{520 \pm 364}{0.68 \pm 0.33}$ & $\frac{147 \pm 56}{0.26 \pm 0.07}$ \\
\hline
\end{tabular}

statistically significantly explained $57 \%$ of the variation in the number and $51 \%$ of the variation in biomass $(p<0.05)$.

In the Middle Yenisei (below the mouth of the Angara), as before, pebbly soils predominate, but the proportion of sand and siltation increase. Homogeneous sandy soils were characterized by the lowest density of $G$. fasciatus (the distribution of samples was statistically different), and Ph. viridis was found only sporadically (Table 3 ). For both species, there was an increase in the number and biomass in the change of soil types "sand-pebble with sand-silty pebble with sand." As in the Upper Yenisei, the amphipods preferred biotopes with higher aquatic vegetation, but there were no significant differences between samples "among macrophytes" and "without macrophytes."

Sandy, silty, and sandy-silty biotopes were distinguished in the lower reaches and the delta of the Yenisei. Low-productive homogeneous sands, as in the previous section of the river, were not an appropriate substratum for the development of amphipods, which were found here sporadically (Table 4). G. fasciatus was also absent on silty soil, having mastered only silty sand and biotopes with macrophytes. The amount of $P$. affinis on the silty soil, on the contrary, increased. Differences between samples when comparing the numbers and biomass of amphipods on different types of soil in the lower Yenisei were not statistically confirmed.

Thus, for all the three species of amphipods studied, there was a tendency to an increase in density in the presence of higher aquatic vegetation. Among the isolated types of soil, G. fasciatus prefers silted bio- topes to a greater extent; $P h$. viridis, on the contrary, is inclined to inhabitation on stony-pebble soils washed by a rapid current. The divergence of ecological niches in $G$. fasciatus and $P h$. viridis is more clearly traced in the Upper Yenisei. $P$. affinis in the lower reaches of the Yenisei has mastered silty and sandy-silty depositions. There were no significant differences in the distribution of crustaceans along different banks and depths.

Analysis of variance of number and biomass of G. fasciatus and Ph. viridis (Table 5) showed that the type of soil and the presence of macrophytes accounted for the maximum proportion of variation of data in the Upper Yenisei (section of Sayanogorsk-Minusinsk)more than $80 \%$ of the number and biomass of $G$. fasciatus and more than $40 \%$ of number of $P h$. viridis. Below in the course of the statistically significant effect of macrophytes, the amount of amphipods was not fixed, and no more than $33 \%$ of the variance was explained by the soil type.

$G$. fasciatus is the most studied among all Baikalian amphipods, as it is one of the most widespread alien species in the freshwater ecosystems of Eurasia. It is a eurybiontic species, resistant to various types of pollution. In particular, in $G$. fasciatus from the Yenisei, unlike $P h$. viridis, there is a decrease in the generation of free radicals with age, indicating a more stable antioxidant system that allows it to cope more effectively with unfavorable environmental conditions (Makarskaya et al., 2016). The high adaptive properties of $G$. fasciatus contributed to its successful deliberate introduction in 22 reservoirs in the European part of Russia, the Urals, Siberia, and Kazakhstan to enrich the food supply of fish (Yanygina, 2015). G. fasciatus is actively 
Table 5. Coefficients of determination $\left(R^{2}\right)$ of abundance $(\mathrm{N})$, biomass $(\mathrm{B})$ of amphipods and habitat factors in different sections of the Yenisei

\begin{tabular}{|c|c|c|c|c|}
\hline \multirow{2}{*}{ Indices } & \multicolumn{2}{|c|}{ Soil type } & \multicolumn{2}{|c|}{ Presence of macrophytes } \\
\hline & $R^{2}$ & $p$ & $R^{2}$ & $p$ \\
\hline \multicolumn{5}{|c|}{ Upper Yenisei (section of Sayanogorsk-Minusinsk) } \\
\hline G. fasciatus $(\mathrm{N})$ & 0.88 & $<0.001$ & 0.82 & $<0.001$ \\
\hline Ph. viridis $(\mathrm{N})$ & 0.46 & 0.033 & 0.41 & 0.014 \\
\hline G. fasciatus (B) & 0.84 & $<0.001$ & $\mathbf{0 . 8 3}$ & $<0.001$ \\
\hline Ph. viridis $(\mathrm{B})$ & 0.22 & 0.263 & 0.14 & 0.185 \\
\hline \multicolumn{5}{|c|}{ Middle Yenisei (mouth of the Angara River-Surgutikha village) } \\
\hline G. fasciatus $(\mathrm{N})$ & 0.27 & $<0.001$ & 0.02 & 0.207 \\
\hline Ph. viridis $(\mathrm{N})$ & 0.33 & $<0.001$ & 0.01 & 0.345 \\
\hline G. fasciatus (B) & 0.26 & $<0.001$ & 0.02 & 0.281 \\
\hline Ph. viridis $(\mathrm{B})$ & 0.34 & $<0.001$ & 0.01 & 0.425 \\
\hline \multicolumn{5}{|c|}{ Lower Yenisei (Dudinka-Brekhov Islands) } \\
\hline G. fasciatus $(\mathrm{N})$ & 0.13 & 0.057 & 0.07 & 0.052 \\
\hline P. affinis $(\mathrm{N})$ & 0.22 & 0.004 & 0.001 & 0.863 \\
\hline G. fasciatus (B) & 0.13 & 0.056 & 0.06 & 0.055 \\
\hline P. affinis (B) & 0.22 & 0.003 & 0.004 & 0.648 \\
\hline
\end{tabular}

In bold type are shown statistically significant coefficients of determination $(p<0.05)$.

spreading from the places of migration upstream and downstream of the watercourses. In 1968-1971, it was deliberately introduced in the Krasnoyarsk Reservoir, from which it descended to the Yenisei from the dam and below, where it coexists or merged with the aboriginal population (Kamaltynov, 2009). Recently, it was first discovered by us in the freshwater Lake Itkul (Khakassia), where it was previously absent, but now coexists with Gammarus lacustris Sars (Andrianova et al., 2015).

The natural habitat of $G$. fasciatus is a shallow coastal strip of Lake Baikal up to $5 \mathrm{~m}$; it is found deeper rarely, reaches a maximum from the edge to a depth of $1 \mathrm{~m}$, and gravitates toward the thickets of aquatic vegetation (Takhteev et al., 2009). In recipient reservoirs, it managed to populate a wide variety of biotopes. For example, in Lake Arakhley, it is characterized by the confinement to sandy soils; in this case, it successfully mastered thickets of macrophytes as well (Matafonov et al., 2006). In the Belovo Reservoir (the $\mathrm{Ob}$ River basin), on the contrary, it lives mainly on solid substrates (boulders, pebbles, gravel in the coastal region); in macrophyte thickets, it is rare and does not reach high abundance (Yanygin et al., 2009).

In the Yenisei, V.N. Greze back in the 1950s (Greze, 1957) revealed the confinement of $G$. fasciatus to silty pebbles in the middle and lower reaches; but this species was especially abundant in the delta on silt-sandy soil and on sand, often among pondgrass growing there. However, in our collections, clean sandy soils in the delta were not populated by amphi- pods (Table 4). For Ph. viridis, as before, there is a preference for pebbly-rocky soils, as is characteristic of it in Baikal. Greze (1957) noted in P. affinis an obvious propensity to dwell on silty and silty-sandy soils, especially in the delta's channels, which is confirmed by modern data.

The divergence of ecological niches in $G$. fasciatus and $P h$. viridis in the Yenisei had already been noted earlier by other authors: Ph. viridis is predominantly distributed on the soil and is more tolerant to low temperatures, $G$. fasciatus is more common among macrophytes and prefers well-warmed sections of the river (Perezhilin, 2013). It was noted that the younger age groups of amphipods prevail in macrophytes. According to studies of Perezhilin (2013), Ph. viridis is the dominant in the gammarocenosis of the Yenisei; however, works were carried out only on one dam site in Krasnoyarsk, where $P h$. viridis had a persistent quantitative advantage over gmelinoides. In our collections on a reach from the Kras-HPS dam to the mouth of the Angara, Ph. viridis in only a few samples was numerically superior to G. fasciatus (Fig. 1), on stonypebble soil at a high flow rate: below the Kras-HPS dam (2500 km from the mouth) and below Krasnoyarsk (village of Rossiyka, $2288 \mathrm{~km}$ ). The dominant position of $G$. fasciatus is confirmed by long-term regular investigations that are carried out within the framework of monitoring in the Roshydromet network at four stations near Krasnoyarsk (Andrianova et al., 2014). 
Table 6. Number (ind. $/ \mathrm{m}^{2}$ ) of amphipods on different soils in the Yenisei River before the commissioning of the Krasnoyarsk HPS (Greze, 1957)

\begin{tabular}{|c|c|c|c|}
\hline Soil type & Angara River-Nizhnyaya Tunguska River & Nizhnyaya Tunguska River-Igarka River & Delta \\
\hline \multicolumn{4}{|c|}{ Gmelinoides fasciatus } \\
\hline Pebble with silt deposit & 1.4 & 1.2 & About 12 \\
\hline Sand & 0.4 & 0.7 & 88 \\
\hline Silty sand & - & - & 304 \\
\hline Silt & - & - & 26 \\
\hline \multicolumn{4}{|c|}{ Philolimnogammarus viridis } \\
\hline Pebble & 2.4 & 0.6 & 6.0 \\
\hline Sand, silty sand & 0.05 & 0.5 & 1.0 \\
\hline
\end{tabular}

\section{Density of Amphipods in Different Periods of the Study}

The distribution of the amphipods of the Baikal complex throughout the whole flow of the Angara and Yenisei has been known for a long time. The first type of amphipods in the Angara River was described by Pallas more than 240 years ago (Kamaltynov, 2009). Then, in 1874, B. Dybovsky for the first time recorded the presence of Baikalian amphipods in the middle reaches of the Angara (Kamaltynov, 2009). In 1929, E.F. Guryanova noted the strong influence of the Baikal fauna already on the Yenisei: "A number of typical Baikal forms, including G. fasciatus and Ph. viridis, penetrate through the Angara into the Yenisei and settle along it both upstream (up to Krasnoyarsk at least) and downstream to the delta, also entering its tributaries" (quoted after Guryanova, 1929). V.N. Greze noted that G. fasciatus and $P h$. viridis are one of the most widespread representatives of the Baikal amphipods in the Yenisei, inhabiting the river from Krasnoyarsk to the gulf inclusive; however, in the Krasnoyarsk-Angara reach, the occurrence of these crustaceans was apparently very low (Greze, 1957). Thus, the main vector of invasion of the Baikal amphipods is self-propagation. However, it is not possible to establish reliably when and for how long the extension of the boundaries of their range occurred in the Yenisei River.

After the regulation of the Yenisei River by the Kras-HPS dam, the fact was established of a multifold increase in the amphipod density above the mouth of the Angara River (Komlev, 1981; Gladyshev and Moskvichyova (Andrianova), 2002; Andrianova, 2013). Thus, prior to the commissioning of Kras-HPS in the 1950s, G. fasciatus and Ph. viridis reached maximum numbers in the delta of the Yenisei: 304 and 6 ind. $/ \mathrm{m}^{2}$, respectively (Table 6). At present, the number of Baikal amphipods in the Yenisei is hundreds and even thousands of individuals per $1 \mathrm{~m}^{2}$, and they have successfully mastered the Upper Yenisei current up to the Sayano-Shushenskoye Reservoir, where phytophilic biocenoses are populated in large numbers (Table 1). The proportion of amphipods in the zoobenthos of the Yenisei has also increased. If prior to regulation the biomass of the crustaceans in the Upper and Middle Yenisei on average did not exceed $10.5 \%$, now it is $50 \%$.

However, in the Lower Yenisei, the quantitative characteristics of amphipods are, according to our data, somewhat lower than in the 1950s (Greze, 1957). Earlier, in the Yenisei delta, the gammarus biomass reached $6.2 \mathrm{~g} / \mathrm{m}^{2}$ in the pelophilic biocenosis, accounting for $60 \%$ of the biomass of the total benthos. According to modern data, amphipods bring only $10 \%$ of the biomass of benthos (less than $1 \mathrm{~g} / \mathrm{m}^{2}$ ). The number of $P$. affinis decreased, the maximum development of which previously occurred in the pelophilic biocoenosis-1600 ind. $/ \mathrm{m}^{2}$, whereas in our study the number was 800 ind. $/ \mathrm{m}^{2}$ (Table 4 ).

Previous large-scale studies of zoobenthos of the Yenisei and, in particular, of amphipod communities were conducted by us in the early 2000s in the section from the Kras-HPS dam to the mouth of the Podkamennaya Tunguska River (Gladyshev and Moskvichyova (Andrianova), 2002; Andrianova, 2013). After a lapse of 15 years, the quantitative characteristics of G. fasciatus and $P h$. viridis did not change significantly (Table 7). However, the density of both species grew statistically significantly below the mouth of the Angara, especially of G. fasciatus -4 times the number and 7 times the biomass. The proportion of crustaceans in zoobenthos also increased.

\section{Geoinformation Web System}

At present, the problem of invasions of alien species belongs to one of the important directions of fundamental and applied research. However, the information component of this kind of research in our country is still insufficiently developed. In Russia, there is a clear lack of Internet resources dedicated to invader species (Dgebuadze et al., 2008).

On the basis of our own data from expeditionary studies, we created a geospatial database with observational results (Fig. 3), which has been placed on the geoportal of the Institute of Computational Modeling 
Table 7. Number (in numerator, ind. $/ \mathrm{m}^{2}$ ) and biomass (in denominator, $\mathrm{g} / \mathrm{m}^{2}$ ) of amphipods in the Yenisei River in the area from the Kras-HPS dam to the mouth of the Podkamennaya Tunguska River in different years of research

\begin{tabular}{c|c|c|c}
\hline Years of research & Amphipods & G. fasciatus & Ph. viridis \\
\hline \multicolumn{5}{c|}{ Kras-HPS dam-mouth of the Angara River } \\
\hline 2001 & $\frac{830 \pm 102(25)}{5.81 \pm 0.85(54)}$ & $\frac{568 \pm 96}{1.66 \pm 0.28}$ & $\frac{245 \pm 40}{3.90 \pm 0.81}$ \\
\hline 2016 & $\frac{962 \pm 311(35)}{4.97 \pm 1.72(47)}$ & $\frac{705 \pm 311}{1.29 \pm 0.45}$ & $\frac{177 \pm 76}{1.90 \pm 0.95}$ \\
\hline \multirow{2}{*}{2001} & \multicolumn{3}{|c|}{ Mouth of the Angara River-mouth of the Podkamennaya Tunguska River } \\
\hline
\end{tabular}

In parentheses-the proportion of amphipods (\%) in zoobenthos.

in a separate thematic section (Geoportal IVM..., 2018a). The geoportal provides tools for visualization and processing of geodata and access to them from third-party applications based on cartographic web services (Yakubailik et al, 2015). The initial filling of the geoinformation system was compiled from the materials of expeditionary research conducted in the early 2000s in the section from the dam of the Krasnoyarsk HPS to the mouth of the Podkamennaya Tunguska River (Andrianova and Yakubailik, 2016; Andrianova et al., 2016). At present, the information resource is supplemented with up-to-date information on the quantitative distribution of zoobenthos, including amphipods, throughout the Yenisei.

The developed geoinformation database with the results of hydrobiological monitoring is available through the standard software web services of the geoportal. Thanks to these interfaces, users are given the opportunity of analytical processing and presentation of hydrobiological monitoring data and export to programs such as Microsoft Excel for further analysis.

On the basis of the prepared geospatial data on the initial geographic coordinates, georeferencing of the observation points of hydrobiological monitoring to kilometer marks along the fairway of the Yenisei was performed; that is, "the system of coordinates of the river" was formed. The use of such a coordinate system differs favorably from the initial information (coordinates in degrees of latitude/longitude), since it makes it possible to evaluate various parameters along the course of the river, while leaving the possibility of working with the original data. Also, a new mechanism was proposed and implemented for displaying contextual information about selected objects on the map-on the basis of templates. Templates allow one to flexibly configure the design and content of an information pop-up window with data about the selected map object: change the style design-color, font options, etc.; place photos; place interactive elements on the form-menus, selectors, etc.; launch external scripts for requests for external data (Kadochnikov and Yakubailik, 2015).

Within the framework of the research stage under consideration, considerable attention was paid to the actualization, systematization, and structuring of information on the hydrography of the basin of the Yenisei River. The feasibility and significance of this work is due to the prospects of complex hydrobiological and hydrographic modeling and the use of spatial analysis methods in geoinformation systems.

With the help of GIS software, a set of multiscale digital cartographic data on the river network in a GIS format was prepared. The developed hydrographic data is not only layers with water objects (rivers, lakes, etc.), but also geospatial information of a special type-databases and GIS layers that allow for a variety of analysis and modeling and visualization of information. The initial data included information from the State Water Cadastre (water register), various tables and handbooks on the characteristics of water bodies from publicly available open resources, and Russian and foreign multiscale digital cartographic data on the river network and catchment areas from various sources. The list of initial geospatial data (raster, vector, digital terrain models) that were used to create the baseplates for the geoinformation system is located on the page of the license agreement of the geoportal of the Institute of Computational Modeling (Geoportal IVM..., 2018b).

At further stages of the work, it is planned to involve methods of geoinformation modeling. Geopositioned hydrobiological information can be compared with other elements of the natural environment-plant cover, soil types, state environmental monitoring data on pollution of the territory, and so on. The river basin in this context becomes a system-forming factor. The 


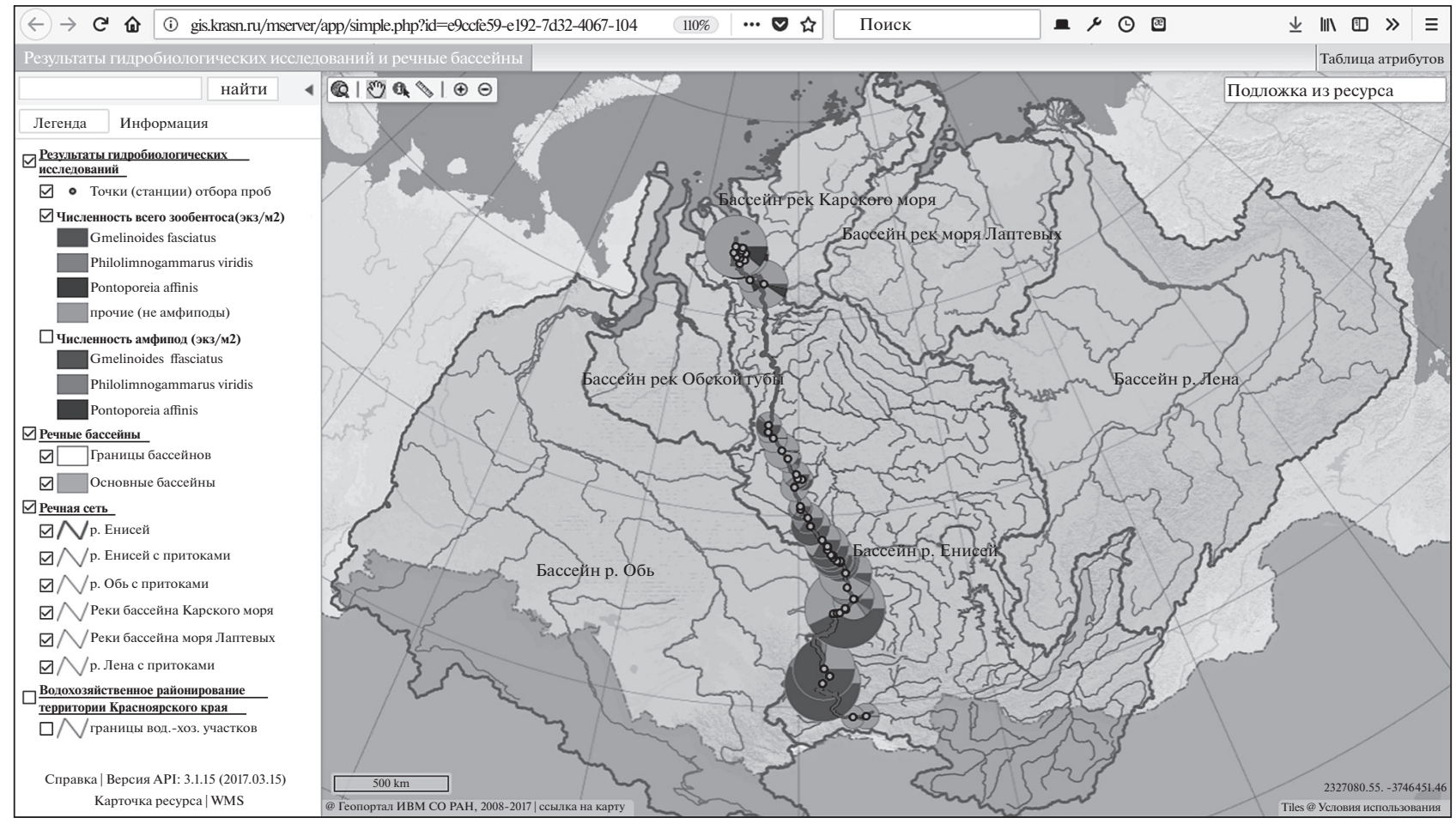

Fig. 3. Web interface of the geoportal of the Institute of Computational Modeling: the river network of the Yenisei River basin, the sampling points for hydrobiological samples, the results of the research (Geoportal IVM..., 2018a).

study of the various characteristics of the ecosystem based on the basin principle links the diverse manifestations of biological life in the territory into one.

\section{CONCLUSIONS}

During the conducted expeditionary research in the Yenisei River, we identified eight species of amphipods, including two representatives of native fauna (P. affinis and Gammarus sp.) and six endemics from Lake Baikal. Throughout the river, gammarids were quantitatively dominated by $G$. fasciatus; $P h$. viridis took second place. Only in the lower reaches and the delta of the Yenisei did the leading positions pass to P. affinis-a representative of the estuary-relic complex of organisms. Baikal endemics most actively populated the Upper Yenisei section below the SayanoShushenskoye Reservoir in places of massive growth of macrophytes.

The main vector of distribution of Baikal endemics in the Yenisei is self-propagation through the Angara River, noted by researchers in the 19th century. For $G$. fasciatus, an additional incentive for the growth of the population below and above the Krasnoyarsk HPS was its deliberate introduction into the Krasnoyarsk Reservoir in the late 1960s with the purpose of enriching the food supply. Naturalization of Ph. viridis in the Upper Yenisei section was probably aided by an accidental introduction.
The features of the spatial distribution of amphipods are related, inter alia, to the type of substrate. The dominant $G$. fasciatus prefers silted biotopes to a greater extent; the subdominant $P h$. viridis, on the contrary, is inclined to stony-pebble soils, washed by a rapid current. The divergence of ecological niches in G. fasciatus and Ph. viridis is more evident in the Upper Yenisei. In the lower reaches of the Yenisei, P. affinis mastered silty and sandy-silty sediments. For all three species of amphipods studied, there was a tendency toward an increase in density in the presence of higher aquatic vegetation. Over the past 15 years, the density and proportion of crustaceans in the zoobenthos have increased in the Angara-Podkamennaya Tunguska area, especially of $G$. fasciatus -4 times the number and 7 times the biomass.

The results are designed in the form of a geospatial database on the geoportal, which provides the ability to visualize hydrobiological information in the form of interactive thematic maps and has direct access to data through cartographic web services from modern GIS. The creation of a geospatial database with the results of long-term expeditionary observations and the formation of special software and technological support for the geoinformation web system associated with it for information and analytical support of hydrobiological monitoring significantly expand the possibilities in the analysis and representation of geodata and form the basis for interdisciplinary research. 


\section{COMPLIANCE WITH ETHICAL STANDARDS}

Conflict of interests. The authors declare that they have no conflict of interest.

Statement on the welfare of animals. This article does not contain any studies involving animals performed by any of the authors.

\section{ACKNOWLEGEMENTS}

This work was financially supported by the Comprehensive Program of Basic Research of the Siberian Branch of the Russian Academy of Sciences "Interdisciplinary Integration Studies" for 2018-2020, the topic "Development of Methods and Web-Oriented Technologies for the Thematic Processing of the Multicellular Hyperspectral Data of Earth Remote Sensing in the Tasks of Ecological Monitoring and Rational Nature Management" (state task no. 0356-2018-0055).

\section{REFERENCES}

Andrianova, A.V., Dynamics of the development of the zoobenthos of the Yenisei River in the tail-water of the Krasnoyarsk Hydroelectric Power Station, Vestn. Tomsk. Gos. Univ., Biol., 2013, no. 1 (21), pp. 74-88.

Andrianova, A.V. and Yakubailik, O.E., Geoinformation web system for hydrobiological monitoring by the example of the zoobenthos of the Yenisei River, Vych. Tekhnol., 2016, vol. 21, no. 1, pp. 5-14.

Andrianova, A.V., Yakubailik, O.E., and Shulepina, S.P., The use of GIS technologies in the analysis of the spatiotemporal dynamics of Baikal amphipods in the Yenisei River, Mater. XI s"ezda gidrobiologicheskogo obshchestva pri RAN, Krasnoyarsk, 22-26 sentyabrya 2014 (Proc. XI Congr. Hydrobiol. O-va, Russ. Acad. Sci., Krasnoyarsk, September 22-26, 2014), Krasnoyarsk, 2014, pp. 17-18.

Andrianova, A.V., Aponasenko, A.D., Makarskaya, G.V., Postnikova, P.V., Ponomareva, Yu.A., and Tarskikh, S.V., Structural characteristics of biological communities of lake ecosystems with different degree of mineralization (Republic of Khakassia), Voda: Khim. Ekol., 2015, no. 12 , pp. $41-47$.

Andrianova, A., Shaparev, N., and Yakubailik, O., Geoinformation support and web technologies for problems of hydrobiological monitoring of the Yenisei River, MATEC Web Conferences, 2016, vol. 79: 01056. doi $10.1051 /$ matecconf/20167901056

Barbashova, M.A., Malyavin, S.A., and Kurashov, E.A., First finding of Baikalian amphipod Micruropus possolskii Sowinsky, 1915 (Amphipoda, Crustacea) in Lake Ladoga, Russ. J. Biol. Invasions, 2013, vol. 4, no. 4, pp. 219-224.

Bazikalova, A.Ya., Amphipods of Lake Baikal, Tr. Baikal Limnol. St., 1945, vol. 11, pp. 1-440.

Berezina, N.A., Invasions of alien amphipods (Amphipoda: Gammaridea) in aquatic ecosystems of North-Western Russia: pathways and consequences, Hydrobiologia, 2007 , vol. 590 , no. 1 , pp. $15-29$.

Berezina, N.A. and Maksimov, A.A., Quantitative characteristics and food preferences of amphipods (Crustacea:
Amphipoda) in the eastern part of the Gulf of Finland of the Baltic Sea, Zh. Sib. Fed. Univ., Biologiya, 2016, no. 4 (9), pp. 409-426.

Dgebuadze, Yu.Yu., Petrosyan, V.G., Bessonov, S.A., Dergunova, N.N., Izhevsky, S.S., Maslyakov, V.Yu., Morozova, O.V., and Tsarevskaya, N.G., Ageneral concept for development of a problem-oriented internet portal on alien species invasions in the Russian Federation, Russ. J. Biol. Invasions, 2010, vol. 1, no. 2, pp. 60-67.

Filippov, A.A., Adaptability of the amphipod Pontoporeia affinis (Crustacea: Amphipoda) to salinity changes, Biol. Morya, 2006, vol. 32, no. 3, pp. 229-231.

Gadinov, A.N., The structure of the zoobenthos of the lower reaches of the Yenisei River before and after the construction of the dam of the Krasnoyarsk Hydroelectric Power Station, in Problemy ispolzovaniya i okhrany prirodnykh resursov Tsentralnoi Sibiri (Problems of Use and Protection of Natural Resources of Central Siberia), Krasnoyarsk, 2007, no. 9, pp. 106-108.

Geoportal IVM SO RAN, Institut vychislitel'nogo modelirovaniya SO RAN (Geoportal Inst. Comput. Model., Sib. Otd., Russ. Akad. Nauk), Krasnoyarsk, 2018a. https://gis.krasn.ru/go/n5p8, Assessed August 15, 2018.

Geoportal IVM SO RAN, Institut vychislitel'nogo modelirovaniya SO RAN (Geoportal Inst. Comput. Model., Sib. Otd., Russ. Akad. Nauk), Krasnoyarsk, 2018b. https://gis.krasn.ru/blog/termsofuse, Assessed August 15, 2018.

Gladyshev, M.I. and Moskvicheva (Andrianova), A.V., Baikal Invaders Have Become Dominant in the Upper Yenisei Benthofauna, Dokl. Biol. Sci., 2002, vol. 383: 138-140. doi 10.1023/A:1015341908129

Gladyshev, M.I., Sushchik, N.N., Shulepina, S.P., Ageev, A.V., Dubovskaya, O.P., Kolmakova, A.A., and Kalachova, G.S., Secondary production of highly unsaturated fatty acids by zoobenthos across rivers contrasting in temperature, River Res. Appl., 2016, vol. 32, pp. 1252-1263.

Greze, V.N., Kormovye resursy ryb reki Enisei $i$ ikh ispolzovznie (Feed Resources of the Yenisei River Fish and Their Use), Moscow: Pishchevaya Prom-st', 1957, vol. 41.

Gur'yanova, E.F., To the Crustacea fauna-Malacostraca of the Yenisei River estuary, Russk. Gidrobiol. Zh., 1929, vol. 8, no. 10-12, pp. 285-298.

Kadochnikov, A.A. and Yakubailik, O.E., Service-oriented web systems for processing geospatial data, Vestn. Novosib. Gos. Univ., Ser. Inform. Tekhnol., 2015, vol. 13, no. 1, pp. 37-45.

Kamaltynov, R.M., Higher crustaceans (Amphipoda: Gammaridea) in the rivers Angara and Yenisei, in Annotirovannyi spisok fauny ozera Baikal i ego vodosbornogo basseina, T. 2: Vodoemy i vodotoki yuga Vostochnoi Sibiri i Severnoi Mongolii, Kn. 1 (An Annotated Checklist of the Fauna of Lake Baikal and Its Catchment, Vol. 2: Water Bodies and Watercourses of the South of Eastern Siberia and Northern Mongolia, Book 1), Novosibirsk: Nauka, 2009, pp. 293-325.

Komlev, V.G., Quantitative changes in the zoobenthos of the Yenisei River in the area Krasnoyarsk City-the Angara River estuary, in Mater. VVses. limnol. soveshch. "Krugovorot veshchestva i energii v vodoemakh, Vyp. 2: 
Elementy bioticheskogo krugovorota," Listvenichnoe na Baikale, 2-4 sentyabrya 1981, Tezisy dokladov (Proc. V All-Union Limnol. Meet. "Circulation of Energy and Matter in Reservoirs, Vol. 2: Elements of Biotic Circulation," Listvenichnoe-on-Baikal, September 2-4, 1981, Abstracts of Papers), Irkutsk, 1981, pp. 138-139.

Kosmakov, I.V., Petrov, V.M., and Zadelenov, V.A., The impact of the change in the Yenisei ice regime below the dam of the Krasnoyarsk power plant on the river ichthyofauna, Georisk, 2011, no, 1, pp. 32-36.

Levadnaya, G.D., Mikrofitobentos reki Enisei (Microfitobenthos of the Yenisei River), Novosibirsk, 1986.

Makarskaya, G.V., Andrianova, A.V., and Tarskikh, S.V., Features of antioxidant activity of tissues in representatives of rheophilic zoobenthos as the results of chemiluminescence analysis, Sib. Ekol. Zhurn., 2016, vol. 23, no. 5, pp. 697-707.

Malmqvist, B., Aquatic invertebrates in riverine landscapes, Freshwater Biol., 2002, vol. 47, pp. 679-694.

Matafonov, D.V., Itigilova, M.Ts., and Kamaltynov, R.M., Features of Gmelinoides fasciatus (Stebbing, 1899) expansion in reservoirs of the Eastern Transbaikalia (by the example of the Arakhley Lake), Sib. Ekol. Zhurn., 2006, vol. 13, no. 5, pp. 595-601.

Opredelitel' presnovodnykh bespozvonochnykh Rossii i sopredel'nykh territorii. Rakoobraznye (The Determinant of Freshwater Invertebrates of Russia and Adjacent Territories. Crustaceans), Tsalolikhin, S.Ya., Ed., St. Petersburg, 1995, vol. 2.

Perezhilin, A.I., Productive characteristics of the dominants of the bentocenosis of the upper Yenisei River on the Divnogorsk-Angara area, Extended Abstract of Cand. Sci. (Biol.) Dissertation, Novosibirsk, 2013.

Ponomareva, Yu.A. and Ivanova, E.A., The ratio of living and dead cells and the size structure of phytoplankton in Yenisei River in the lower reaches of the Krasnoyarsk power plant, Sib. Ecol. Zhurn., 2016, no. 5, pp. 706-717.

$R$ Core Team, R: A Language and Environment for Statistical Computing, R: Foundation for Statistical Computing,
Vienna, Austria, 2014. http://www.r-project.org, Assessed August 15, 2018.

Rukovodstvo po gidrobiologicheskomu monitoringu presnovodnykh ekosistem (Guide to Hydrobiological Monitoring of Freshwater Ecosystems), St. Petersburg: Gidrometeoizdat, 1992.

Sorokovikova, L.M. and Bashenkhaeva, N.V., Eutrophication and water quality in the Yenisei River, Vodn. Resur., 2000, vol. 27, no. 4, pp. 498-503.

Takhteev, V.V., Berezina, N.A., and Sidorov, D.A., Checklist of the Amphipoda (Crustacea) from continental waters of Russia, with data on alien species, Arthropoda Selecta, 2015, vol. 24, no. 3, pp. 335-370.

Takhteev, V.V., Sudakova, E.A., Matveev, A.N., et al., Biota vodoemov Baikal'skoi riftovoi zony (Biota of the Reservoirs of the Baikal Rift Zone), Irkutsk, 2009.

Yakubailik, O., Kadochnikov, A., and Tokarev, A., Applied software tools and services for rapid Web GIS development, Informatics Geoinformatics Remote Sensing, 2015, vol. 1, no. 1, pp. 487-496. doi 10.5593/SGEM2015/ B21/S8.060

Yanygina, L.V., Spatial distribution of Gmelinoides fasciatus Steb. in thermally polluted water (Belovo Reservoir, Southwest Siberia), Int. J. Environ. Res., 2015, vol. 9, no. 3 , pp. $877-884$.

Yanygina, L.V., Kirillov, V.V., and Zarubina, E.Yu., Invasive species in the biocenosis of the cooling reservoir of Belovskaya power plant (Southwest Siberia), Russ. J. Biol. Invasions, 2010, vol. 1, no. 1, pp. 50-54.

Zadelenov, V.A., The current status of populations of sturgeons (Acipenseridae) and their food base in the Yenisei Basin, Sib. Ekol. Zhurn., 2000, vol. 7, no. 3, pp. 287291.

Zuev, I.V., Vyshegorodtsev, A.A., Chuprov, S.M., and Zlotnik, D.V., Modern composition and distribution of alien fish species in the water bodies of the Krasnoyarsk Territory, Russ. J. Biol. Invasions, 2016, vol. 7, no. 4, pp. 324-332.

SPELL: 1. OK 